\title{
Universality and Modern Individuality Civilization Paradigm in The Field of Human Rights: Dialogue vs Conflict
}

\author{
By Svitlana Karvatska ${ }^{1}$, Lyubov Zamorska ${ }^{2}$, Olga $\mathrm{Chepel}^{3}$, Tetyana Gnatuyk ${ }^{4}$, \\ Iryna Prodan ${ }^{5}$
}

\begin{abstract}
The article gives reason to say, that the key point of globalization in the field of human rights is the universalization of this area. The universalization of human rights is a key trend, but not the only, in their development. Human rights as universal moral principles specification are the rules on which peaceful coexistence of individuals and different cultures in terms of global problems is possible. Such an approach allows to solve the seemingly irreconcilable contradiction between the positions of the universalism of human rights and cultural identity pluralism: the right to cultural identity is a significant individual right. There should be a critical approach to the thesis of the insurmountable fundamentality of cultural differences between Eastern and Western cultures. It is necessary to distinguish between situations of imposing Western standards on other cultures and the real importance and universality of human rights for the modern world. Cultural diversity should never be used as an excuse for chauvinistic nationalism. It is intercultural dialogues that should facilitate fruitful exchanges of ideas on human rights issues in the perspective of cultural diversity and become the basis for the formation of a dialogical civilization. Contemporary human rights discourse has to take place in the context of a global world order emergence through the juxtaposition of concepts such as universality, cultural diversity and cultural dialogue.
\end{abstract}

Keywords: globalization, buman rights sphere, legal standards, dialogical civilization, intercultural dialogue

\section{Introduction}

A globalization process is one of the main global trends of modern times. The key point of globalization in the field of human rights is the universalization of this area. Human rights as a scientific phenomenon and the universal heritage of legal culture, regardless of the forms of their expression, is the cornerstone of the preservation and development of humanity, not only law but also all other legal phenomena. The problem of human rights is relevant both in the context of the multipolarity of a particular legal system development and civilization in general. Human rights and freedoms go through all stages of development of

\footnotetext{
| ${ }^{1}$ LL. D (Doctor in Law), Associate Professor, Department of European Law and Comparative Law Studies, Yuriy Fedkovych Chernivtsi National University

2LL. D (Doctor in Law), Associate Professor, Department of Theory and Human Rights, Yuriy Fedkovych Chernivtsi National University

3Ph. D in Law, Associate Professor, Department of European Law and Comparative Law Studies, Yuriy Fedkovych Chernivtsi National University

${ }^{4} \mathrm{Ph} . \mathrm{D}$ in Law, Senior Lecturer, Department of European Law and Comparative Law Studies, Yuriy Fedkovych Chernivtsi National University

${ }^{5} \mathrm{Ph} . \mathrm{D}$ in Law Student, Department of Theory and Human Rights, Yuriy Fedkovych Chernivtsi National University
} 
civilizations and cultures, which not only preserved their identity, contributed to the formation of communities and states, but also gradually began to play a crucial role in improving man himself in the context of different traditions and cultures.

Human rights are universal. The theoretical and legislative basis for the universalization of human rights and freedoms are universal human norms, international agreements and documents that have been adopted and ratified by various countries (Karvatska \& Zamorska: 2018, 5 (2), 1-14). To ensure globalization, it is important to develop common legal standards, covering legal standards in the field of individual rights and freedoms (Karvatska, Blikhar \& Huralenko, 2021: 39 (68), 88-102).

However, it should be noted that human rights are a multifaceted and versatile phenomenon. The diversity of human rights comes from the nature of man himself, his interests are diverse and often exist within the framework of philosophy, morality, religion, law, politics, economics. In general, the universality of human rights means that the state is accountable to its people and to the international community for fulfilling the obligations it undertakes by acceding to international human rights treaties (Chepel, 2019: 6 (2), 1-10). Regardless of a well-established debate over universalism against cultural relativism, the line between universality of human rights on the one hand and respect for local practices and traditions on the other remains blurry. This tension metamorphoses into the coexistence and overlap of universal and regional human rights systems because the latter reflects an effort to try to reinforce fundamental rights protection while emphasizing regional particularities and shared values shared by some states, as opposed to a unified system, accused of ignoring the unique characteristics of each region.

This article aims to analyze the issue of human rights in terms of cultural pluralism and the possible basis for the development of a dialogical civilization.

\section{Methods}

The methodology of this study is based on a comprehensive approach to the concept of universality of human rights analysis, which is due to the specifics of the topic of the work and is associated with the use of general and special scientific methods of cognition. In the process of solving the given tasks, a general scientific dialectical method was used to clarify the essence of the universality of human rights.

The following methods were used at some stages of the work: comparative law - in the process of considering natural law, positive and other approaches to understanding the nature of human rights, as well as when comparing the idea of universality and relativity of human rights; hermeneutic - in the study of universalization of human rights concept in the context of globalization; systemic and structural-functional - in the analysis of common legal standards in the field of human rights; formal-legal - in the disclosure of the provisions of regulations that proclaim the principle of human rights` universality.

\section{Discussions and Results}

\subsection{Universality of human rights concept: the past and present challenges of universalization}

Universalization of human rights is a universal, comprehensive nature of human rights, versatility and adequate application to any person, society, regardless of their 
distinctive features. The theoretical and legislative basis for the universalization of human rights and freedoms are universal human norms, the activities of various public organizations and various packages of international agreements and documents that have been adopted, signed and ratified by different countries.

To ensure globalization, it is important to develop common legal standards. Such standards today apply to various areas of legal regulation and, above all, cover legal standards in the field of individual rights and freedoms. International standards of human rights and freedoms have been enshrined in regulations relatively recently - in particular, the main one is the Universal Declaration of Human Rights, 1950. The Declaration includes paragraphs on the universalization of universal values of goodness, solidarity, freedom of thought and conscience, equality before the law, the role and significance of an individual in the social system. This Declaration, together with the International Covenant on Civil and Political Rights of 1966, the two Optional Protocols and the International Covenant on Economic, Social and Cultural Rights of 1966, is, in fact, the International Bill of Human Rights (showed in the graph bellow).

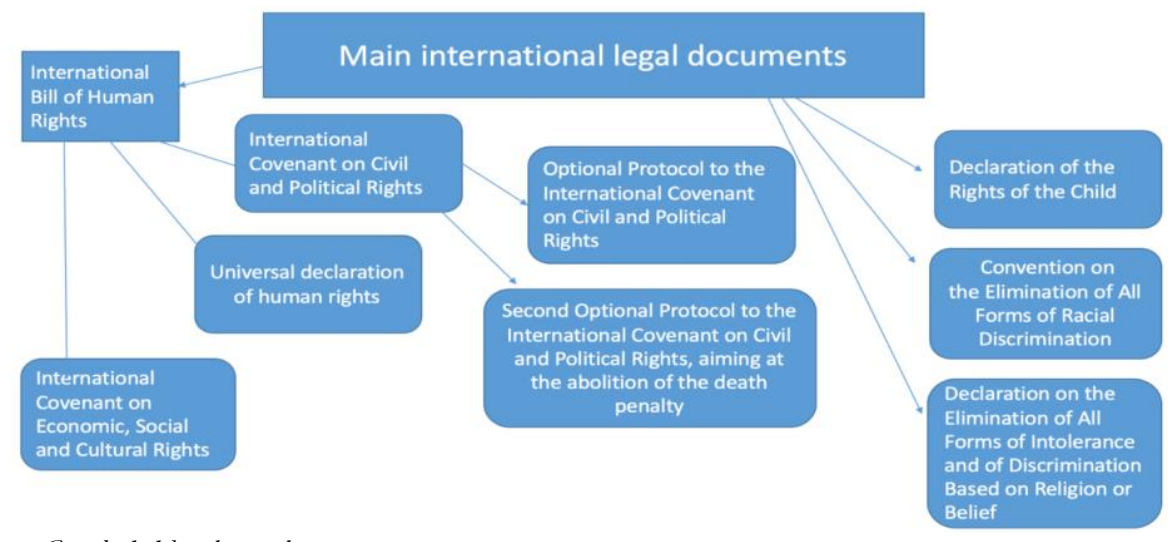

Source: Concluded by the authors

Representatives of absolute universalism speak about the possibility of applying a single, universal concept of human rights worldwide. Any differences based on the principle of regionalism are unacceptable. Synonymous with the concept of absolute universalism, which traditionally characterizes the moral concepts of a society, should be considered the concept of monism. Representatives of this trend believe that a man as a person from a certain society can not only evaluate the moral systems of other societies, but also establish what way of life the real human life is. 


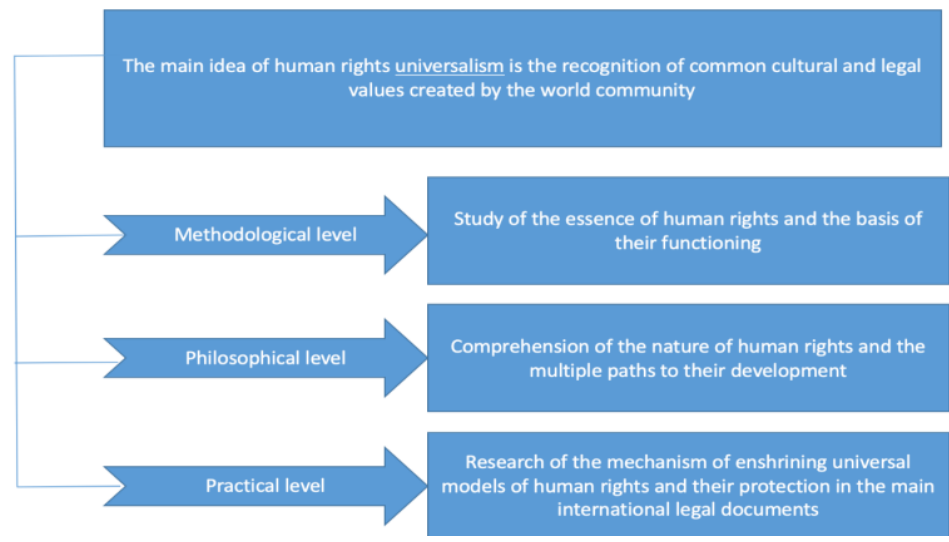

Main ideas of human rights universalism

Source: Concluded by the authors

The Universal Declaration of Human Rights is considered a landmark in the human rights movement internationalization (Donnelly, 2003: 22). Nonetheless, the claim that human rights are inherent does not imply that all nations must instantly recognize them. There is a large disparity between where widely accepted assumptions are formed and the specific conditions in which they should be applied, as well as between the theoretical and practical execution of human rights norms by nations.

Anthropologists have questioned the universality of human rights, claiming that man is molded by his culture's customs and beliefs, rather than being a product of his own free will. As a result, it is critical to recognize and appreciate cultural differences. Consequently, as people are conscious of their character, behavior, moral values, and cultural experience, respect for individual differences involves respect for cultural differences. As a result, respect for individual diversity includes respect for cultural variations, as people are aware of their character, behavior, moral ideals, and cultural experience. (American Anthropological Association, Statement on Human Rights: Oct-Dec 1947, 49, 4(1), 539). In the 90s of XXth century S. Huntington (1996) pointed out that Western ideas are fundamentally different from those of other civilizations. S. Huntington (whose ideas have been repeatedly criticized) argues that in Islamic, Confucian, Buddhist and Orthodox cultures there is almost no response to such Western ideas as individualism, liberalism, constitutionalism, human rights, equality, freedom, rule of law, democracy, free market, separation of church and state. And the very thesis of the possibility of "universal civilization", according to S. Huntington - is a Western idea and it is in direct conflict with the particularism of most Asian cultures, with their emphasis on the differences that separate some people from others" (Huntington, 1996).

In the late twentieth century, it was again Southeast Asia where a turning point in human rights history happened. The East Asian values theory, criticizing human rights universalism, argued in favor of so-called relative values of human rights in different societies. A complete distinction was drawn between a West recognized as a place for liberté and equality and, on the other hand, the East, where liberté is not a pivotal category. (Barreto: 2018, 46, 484-502). The concept of the universality of human rights is criticized on the grounds, that the very idea of human rights is the fruit of Western Protestant culture (only sometimes the general 
Christian roots of this idea are meant), and, therefore, it is not organic to other cultures and civilizations. Authors who recognize the universality of human rights, but think that human rights are not a discovery of the West, but underlie Islamic doctrine and Confucianism, also speak from anti-Western positions. However, in this case, steps towards rapprochement with Western human rights theory and the search for consensus are not excluded. Cultural diversity does not exclude, but assumes the universality of human rights as universal values. Yet, in the position of the universality of human rights critics, one can single out a rational grain. It is worth agreeing with the opinion of $\mathrm{E}$. A. Lukashova (2007: 243) on the inadmissibility of forcing the process of universal human rights standards perception by non-Western cultures.

A natural question arises as to whether the concept of "culture" does not cover those behavioral practices that are violence from the point of view of another culture? The fact is that the right to culture is exercised until its realization is an encroachment on any other human right, and such references to cultural rights or their interpretation that justify an action leading to violation of other rights and fundamental freedoms are not allowed. International standards on human rights, inherent in the concept of human dignity and justice vary depending on cultural and social ideas. National or local governments frequently undermine the validity of human rights treaties by questioning local customs based on traditions and beliefs to social cohesiveness and the maintenance of the status quo. Cultural practices and traditional beliefs are frequently used to legitimize discriminatory policies and human rights breaches, according to Higgins and Tracy (1996: (19), 114). Furthermore, cultural and social standards serve as a foundation for the authority and control of people who lack the resources to struggle for social change.

Moderate universalism occupies an intermediate position between monism (absolute universalism) and relativism. Representatives of this trend share the postulate that moral life can be organized in different equivalent ways. On the other hand, strong universalism (radical egalitarianism) imposes a veil on the differences that really exist. Universalist orientation in its strong form can lead to value absolutism, which does not take into account the diversity of value systems around the world and changes in values over time. Regardless of the dynamics and the specific circumstances, absolutism might lead to authoritarianism, which is inconsistent with the idea of human rights. Although the essence of a strong universalism idea is to overcome any discrimination, as its critics aptly argue, it ignores the differences that can lead to policies in fact biased against different socio-cultural groups.

The question arises if human rights are based on human nature, and if human nature is universal, how can human rights be relative? After all, human nature itself is, to some extent, limited by culture.

Despite the fact that the human rights community believed that their universality was "without doubt," it was disputed from the start. During debates on the UDHR declarations preparation, the representative of Saudi Arabia Baroody denied the bias of the West regarding this document, accusing the authors of the project of taking into account only the standards recognized by Western civilization. (Third Committee of the United Nations General Assembly (November 9, 1948: 370). In practice, nevertheless, there is a disparity between the kind of universal human rights vocabulary and consensus on the conceptual foundations, extent, and meaning of human rights (Mutua, 1996: 36, 590).

The universalization of human rights is a key tendency, but not the only one, in their 
development. In particular, a number of authors quite reasonably prove the existence of regionalization processes along with the processes of universalization of human rights. Regionalization in the field of human rights is seen as a process of creating standards and control mechanisms for the protection of human rights in accordance with the traditions and culture of regional entities. But still regionalization is one of the universalization stages. That is, regionalization is essential to overcome national borders, because the implementation of certain standards in the process of regionalization goes on with preserving the cultural and spiritual features of the region, so the transition from purely national to supranational regulation of human rights is more "smooth".

The universal standard of human rights represents a broader consensus concerning human dignity, than any single culture or tradition. Therefore, cultural differences should not be grounds for discrimination and its justification; thus, discrimination is the deprivation of human rights on the basis of inherent cultural differences, in addition to the unlawful deprivation of human rights.

\subsection{Can there be universal human rights in a culturally diversified world?}

How to reconcile human rights with the clash of cultures that has become a feature of our time? After all, the cultural basis is one of the main components of personality. It largely defines such categories as self-perception, self-expression and a sense of belonging to a particular socio-cultural group. As cultures interact, so does the culture of the individual. This process can both enrich and disorient a person. This situation aggravates a longstanding dilemma: how can there be universal human rights in a world so diverse, heterogeneous and contradictory? How to ensure equal respect for cultural diversity, on the one hand, and integrity in the context of the world community integration, on the other? At the World Conference in Austria, the subject of whether the right to multiculturalism undermines the universality of human rights was debated (170 states participated in the adoption of the Declaration and a consensus was reached).Despite the existence of different approaches, the UN World Conference on Human Rights, as articulated in the Vienna Declaration and Program of Action, June 25, 1993, reaffirmed the universality of human rights, although also stressed the need to remember regional peculiarities - article 5 emphasized, that "it is the duty of states, regardless of their political, economic and cultural system, to promote and protect all human rights and fundamental freedoms". The main provisions of the Program of Action of the World Conference on Human Rights have become the subject of faith of the international community: "the universal nature of these rights and freedoms is beyond question."

General principles enshrined in the UDHR, are declarative by their philosophical and legal nature: they must be filled with specific content in the context of a particular civilization. But it is incorrect to impose human rights standards by force on another cultural community. As I. Chestnov (1999: (1), 82) emphasizes, the West must treat other civilizations with respect and instead of a monologue ... should learn to conduct a dialogue. According to E. A. Lukasheva (2007: (77), 2, 117), a civilization approach should be used in this regard. This approach makes it clear that other civilizations have their own "self-evident truths", and these truths do not always coincide with the European ones. Rooted in the minds of peoples for millennia, they are a barrier to the unconditional acceptance and realization of human rights proclaimed in international legal documents, 
despite their recognition by national law. The explanation for this should be sought in the inseparable connection of human rights content with the system of other normative regulators - religion, morality, customs, traditions, higher values of this or that cultural and historical type. They are determined by the image of man and the image of the world in which he is formed (Lukasheva, 2007: (77), 2, 117).

One should not continue to base the notion of human rights on previous universal principles detached from geopolitics, and Europe, the traditional wellspring of human rights, has been changed into one of the provinces where their history is still being written. This is not to say that the Western view of human rights is unavoidable; rather, it must be "updated from beyond the field limits" (Chakrabarty, 2007: 16).

We can agree with the supporters of the cultural relativism doctrine, that different traditions and cultures of states in different ways affect both the values directly and the understanding of the content of universal values. In turn, this is reflected in the implementation of sometimes different policies and practices in the field of human rights protection by different countries of the world. Despite the general democratic nature of such common values, they contain different formulations and interpretations of different political and socio-economic content. That is why, universal rights set out in fundamental human rights documents, even for states which have ratified them, will depend on specific features of a separate state. Recognition of these values at national level is a manifestation of universality, which at the same time coexists with cultural and national diversity (Mytsyk, 2010: 53).

The plus of cultural relativism has been that it rejects ethical absolutism, which involves claims of infallibility; yet, the problem with relativism is that it supports extreme pluralism, tolerating cultural disagreement without attempting to resolve it. Azadeh Chalabi (2020) contends that cultural practices including female genital mutilation (FGC), leg binding, "sati," or even slavery in some instances can be adopted by individuals who promote relativism, whether officially or tacitly.

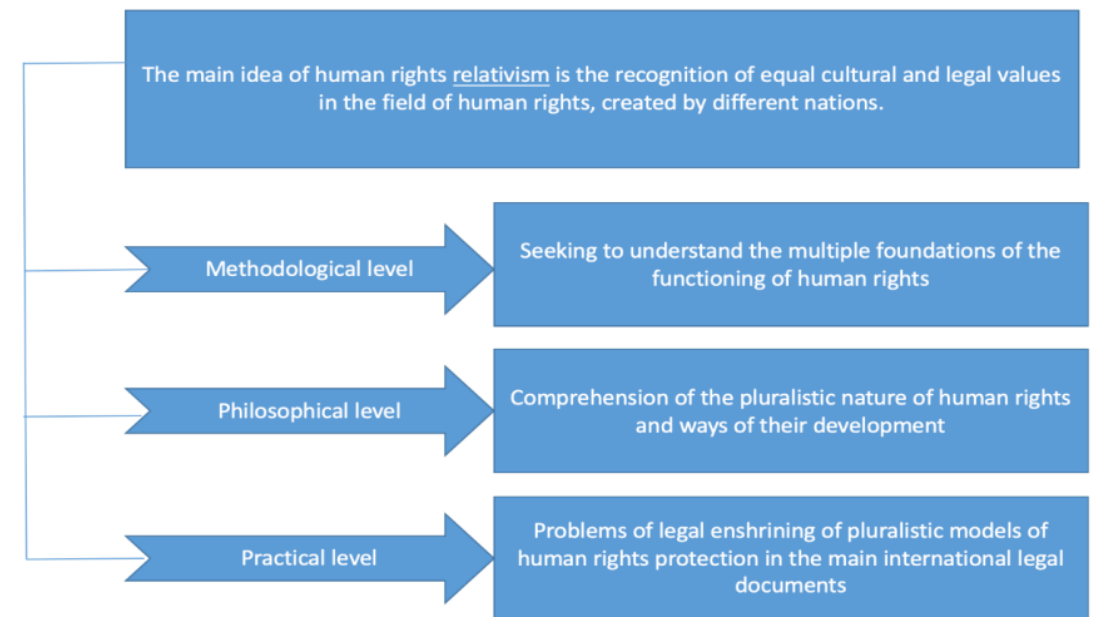

Basic levels of the relativity of buman rights idea

Source: Concluded by the authors

The impact of Islamic religious law on Muslims' public and private lives exemplifies the 
idea that local traditions influence human rights. This is due to the fact that Sharia norms encompass all domains of human behavior, both permitted and prohibited, as well as advised or justified, thereby touching person's conscience in all capacities: private, public, and official. All areas of life are governed by this global system of law and ethics. Specific elements of Islamic law may or may not accord with human rights and globally renowned requirements, depending on how they are interpreted and applied in different countries. T. Jeremy Gunn (2020: 149 (3), 159) cites five cases of legal activities that breach the UDHR (states with a majority of Muslims). First, certain countries ban Muslim women from marrying non-Muslim males, in violation of the UDHR preamble's gender equality ideals. Second, specific states have passed laws that provide for a distinct division of inheritance, prioritizing men, contrary to the UDHR preamble and art. 2 principles of gender equality. Third, certain Muslim states prevent non-Muslims from adopting Muslim children while allowing Muslims to adopt non-Muslim children, violating the UDHR preamble and art.18 principles. Fourth, certain states prohibit non-Muslims from converting to Islam, violating the UDHR preamble and art. 18, enabling non-Muslims to convert to Islam. Fifth, certain Muslim majorities demand that the chef d'état be a Muslim, despite the preamble and art. 18 of the UDHR. Gunn (2020: 149 (3): 160) asserts that the opponents of human rights universalism are those who promote the modern national state's ability to ensure adherence to the state's interpretation of Islamic law, rather than those who defend the right of Muslims to practice their religion per Islamic law.

In the area of religious rights, the denial (or even opposition) of international human rights norms in portions of the Muslim and Arab countries is particularly revealing. To begin with, "rejection" relates to the right to freedom of thought, conscience, and religion (art. 18), the ban of discrimination based on religion (art. 2), and the prohibition of discrimination against women (preamble, art. 2, art. 16). Such a resistance to universal standards prescribed in the UDHR, traced on the provisions of the International Covenant on Civil and Political Rights (ICCPR), the norms of the Convention on the Elimination of All Forms of Discrimination against Women, as well as the main provisions of the Convention on the Rights of the Child, and the 1981 Declaration on the Elimination of All Forms of Intolerance and of Discrimination based on Religion or Belief. I.e. the laws related to religion, to which the Arab and Muslim world is particularly "sensitive" must go through socio-cultural filter of understanding on the way to universal standards, or without the state intervention non-Muslims in countries with Muslim majority confess their religion and adhere to their own religious practices. Gunn (2020) discusses the Sunni's freedom to change religion, as well as women's rights to inheritance, marriage, divorce, and child care on the same conditions as men-Muslims. According to him, the term Sharia has been employed "to legitimize a Muslim exception to a universal standard" since the 1980s (Gunn, 2020).

Regional systems, on the other hand, share characteristics drawn from the universalistic idea of human rights. The UDHR and the concepts developed from it are referenced in relevant treaties creating regional systems (preamble of the American Convention on Human Rights, African Charter on Human Rights, and European Convention on Human Rights), therefore enhancing the universality of human rights. Its standards, regional agreements, and worldwide accords establish convergent human rights concepts, taking into consideration "cross-references and mutual impact in jurisprudence," supporting the 
premise that various regimes enhance each other. Flávia Saldanha Kroetz (2019) refutes the idea that regional human rights regimes obstruct proper protection of human rights by requiring universality.

In both respects, the individualized West against the group-oriented East is a mockery. A discourse that link an individualistic nature of human rights to a fact that that they are individualistic because they defend personal freedoms disregards the reality that all people are individuals who are all protected by their universal aspirations. Religion-related human rights, expressly stated in the Universal Declaration of Human Rights, are directly described as suitable for people individually and together with others (Gunn: 2020, 149 (3), 148-169).

N. K. Agyeman and A. Momodu (2019: (1), 23-46) claim that the antagonism context of universalistic and relativistic concepts of human rights is subjectively exaggerated. The authors believe that the constitutional process of constitutional rights guarantee, which is based on international principles of human rights aims both at universalistic and relativistic ideals.

On the table are timeless issues including how to reconcile the universality of human rights and cultural relativism. If we assume that universalism and relativism are generally antipodal rather than incompatible, a mix of mild relativism and mild universalism may be the way ahead.

The idea of human rights is not Western or Eastern, but rather an evolutionary account. In this regard, some scholars have cited various examples to show that the idea of human rights has no boundaries in time or place. For example, Azadeh Chalabi (2020) refers to William Talbott, who argues that human rights do not belong to certain cultural traditions, and it is a mistake to believe that Western Europe has a tradition of religious tolerance, since the first known adherents of religious tolerance was the East - in particular, Cyrus the Great (VI century BC, King of Persia, Iran). While slavery in the USA remained a legitimate institution until the end of the XIX century, back in the VI century BC Cyrus eliminated slavery.

Martha Nussbaum's (1999: 214) theory that gender equality is an Indian constitutional notion, not an American constitutional one, supports Azadeh Chalabi's (2020) position. Instead, the author underlines that in the East, basic human rights are infringed on a daily basis. Despite the existence of a basic agreement on the rights of persons with restricted capacities, there is still a prevalent belief in India that disability is a personal handicap and a result of karmic punishment for misdeeds (Chalabi).

The notions of universalism and cultural relativism are not mutually exclusive. Instead of seeing universalism and cultural relativism as incompatible adversaries, the conflict between the two perspectives must be viewed as part of a constant conversation. Contemporary human rights discourse must be pursued in the context of the emergence of a global world order through the juxtaposition of the concepts, such as universality, cultural diversity and cultural dialogue.

\subsection{Intercultural dialogue problems in globalization conditions in the context of Ukraine}

Despite the strong impact of globalization on the unification of social structure and distribution of western-centric lifestyle, the existence of numerous ethnic, religious 
and cultural groups determines the impossibility of a single correct and valuable sociocultural paradigm. The very phenomenon of globalization has given rise to another phenomenon called regionalization: in a world of unified values different social groups set the task of preserving their own identity. In legal sphere the questions of identity raise, in turn, a layer of reflections on human rights values within a particular paradigm: first, what is human rights, and whether there should be uniform criteria for their determination.

It is intercultural dialogue that can facilitate universal discourse without undermining cultural diversity. It is necessary to develop the rules for such a dialogue, an important condition of which is communication and partnership. The policy of cultural identity on the basis of eternal ties must be recognized in all cultural and legal dialogues. Cultural diversity has no right to be used as an excuse for oppression of interests and chauvinistic nationalism. Therefore, intercultural dialogues should facilitate the effective exchange of ideas on human rights issues in the context of cultural diversity and become the basis for the formation of a dialogical civilization.

In the Ukrainian reality, the problem of determining the national position on intercultural dialogue in human rights ' domain is complicated by a number of social, political and cultural factors. However, no single moral values of Ukrainian society is the main obstacle here: lack of consensus concerning ideological foundations of society makes it impossible to isolate a single Ukrainian answer to a number of global challenges, the questions of human rights, in particular.

The political polarization of Ukrainian society causes inefficient work of state institutions, unstable political system, destructive processes in the work of authorities. Since the time, when the famous Ukrainian ideologist of the early 20th century Mykhailo Hrushevsky put a question "Who are Ukrainians and what do they want?" existentially our society has not yet been ready to solve these tasks: different social communities in different geographic regions, have different vision of the civilization paradigm. Since Ukraine has no real concept of "elite", Ukrainian political elite, unfortunately, doesn't contribute to creating common identity and becomes only an embodiment and reflection of different political views and private political interests.

O. Yuriychuk (2018) identifies the value components of the nation's legal identity: so, the nation's awareness of its independence and uniqueness contribute to understanding the national idea as a spiritual culture phenomenon and the basis of state formation, cultural identity as a form of representation and separation in the multicultural international arena, as well as original legal values, which are a major factor in the formation of the nation as a systemic creation.

The relevant provision is reflected in art. 11 of Ukraine's Constitution, which provides that the state facilitates the consolidation and development of the Ukrainian nation, its historical consciousness, traditions and culture, as well as the development of ethnic, linguistic and religious identity of all indigenous peoples and national minorities of Ukraine. But it should be noted that cultural identity in Ukrainian realities is, first of all, the search for mechanisms of state interaction and pluralism of cultural entities and their application in practice: creation of concepts and cultural development programs, protection of human rights and public interests.

But, determining the legal interests of the nation, it is necessary to apply a scientific approach that should take into account the historical, socio-political and economic- 
geographical factors of Ukrainian nation's functioning. In this context, the main thing is to understand what the modern Ukrainian nation is as an ethnically homogeneous community of Ukrainian citizens living in Ukraine, and an open poly-ethnic community that has historically developed in Ukraine, considering itself a part of Ukrainian nation, and its members - citizens of Ukraine (Krysachenko, 2004 : 181-211, Rymarenko, 12-87) . For Ukraine, which is a relatively young state that is constantly in a state of national democratic development, the emergence and formation of which as a sovereign European state is a global historical, political and legal phenomenon, the problems of global transformation and global integration are particularly acute. They are to some extent layered on complex domestic processes associated with the creation of the state and civil society, the emergence of a market economy, the formation of a new worldview of society. As a result, important problems of self-identification, transformation and development accumulate and become hopeless, but this fact does not eliminate the need to solve them in the near future. Today, Ukraine needs to enter a globalized world and solve internal problems, at the same time. In modern conditions, the success of solving problems important to a particular state, very often depends on the political will of other states. Despite the economic power of individual countries, their impact on the international economy and politics, globalization should not be reduced to their subjugation of sociocultural values of other, less powerful countries, including Ukraine. Not conquest, but mutual enrichment of spiritual and cultural life under the condition of equal existence of cultures - this is what the globalization process requires.

The social community of Ukraine is spiritually divided not only by inherited from the past divergence of political interests and religious preferences, which can be traced according to both territorial and linguistic characteristics (West - East), determining the population's attitude to the proclamation of the Ukrainian language as a single state language. The key problem is the choice of an integration vector, preferred by one or another part of the population, in particular by generational characteristics: young people are inclined to perceive European values, in contrast to the elderly population, which still retains the Soviet identity. Spiritual integrity as a unity of values is not still achieved. The national idea did not take its place among the national identification features, the main factor of which could be the definition of Ukraine's integration guidelines, as a guarantee of successful inclusion of our state in globalization processes. Therefore, for Ukraine, the comprehension of values that would simultaneously express both the historical experience of the Ukrainians and the world civilization values in the public consciousness is fundamental.

In the conditions of society transformation, under the pressure of global problems, selfidentification of Ukrainian society, identifying oneself with a certain political and civilization community is difficult and contradictory in Ukraine. The role of political parties, public organizations, and government agencies should be more important and responsible in this process. The unifying self-identification factor should become an important standard in the development of the Ukrainian state.

\section{Conclusions}

The Universal Declaration of Human Rights establishes a somewhat contentious 
agreement on the fundamental principles and objectives of individual dignity and equality deriving from international human rights legislation.

The universalization of human rights is an important, but not the only, trend in their development. Cultural diversity should never be used as an excuse for chauvinistic nationalism. It is intercultural dialogues that should facilitate fruitful exchanges of ideas on human rights issues in the perspective of cultural diversity and become the basis for the formation of a dialogical civilization. Modern human rights discourse must be pursued in the context of the emergence of a global world order through a juxtaposition of concepts such as universality, cultural diversity and cultural dialogue, which can facilitate universal discourse without undermining cultural diversity. It is necessary to develop rules for such a dialogue, an important condition of which should be communication and partnership. The policy of cultural identity on the basis of eternal ties must be recognized in all international dialogues.

The concepts of universalism and cultural relativism are not antagonistic: dissimilar cultural and legal positions should be considered as part of objectively productive dialogue. It is obvious, that a "road map" is needed, leading from the criticism of Western thinking and euro-centric concepts to the dialogue on human rights protection in the context of the new millennium challenges. Therefore, the concept of the universality of human rights should be based not just on civilization, but on an inter-civilization approach. This approach focuses on the pluralism of interpretation and the idea of coexistence of different cultures, with different systems of traditions and values. These factors refute the assertion that regional human rights systems obstruct proper protection and promotion of human rights at the regional level and weaken the UN system's efficacy.

The contemporary problems of Ukraine are not purely domestic. Human rights have ceased to be a purely internal affair of individual states, and have become the object of international regulation. In addition, in conditions of uncertainty in a transforming society, the divergence of rights and opportunities for their realization is intensifying.

The dependence of the realization of the right level on social capital gives grounds to speak about social capital of all mankind. That is why international law should be the basis for the formation of social capital of mankind - a relationship of fair and equal cooperation and partnership.

Human rights as a concretization of universal moral principles prove to be the norms, on the basis of which the peaceful coexistence of individuals and different cultures is possible, as well as their cooperation in the face of global problems. This question allows us to resolve the seemingly irreconcilable contradiction between the positions of universal human rights and pluralism of cultural identity, namely, the right to cultural identity can be considered as a meaningful individual right for all people. The thesis of the insurmountable fundamentality of cultural differences between Eastern and Western cultures should be criticized. Therefore, it is necessary to distinguish between situations of imposing Western standards on other cultures and the real importance and human rights universality for a modern world.

Analyzing a relationship problem between human rights universality and cultural relativism at their present development stage, it can be argued that along with the universal rights of each member of the human race, regional civilization standards of rights should be developed, and they would reflect national and historical specific features and cultures 
of different nations.

\section{References}

Agyeman, Nana Kwame \& Momodu, Alfred. (2019). "Universal Human Rights 'Versus' Cultural Relativism: the Mediating Role of Constitutional Rights". African Journal of Legal Studies. 12, (1), (Dec 2019), 23 46 DOI: https://doi.org/10.1163/17087384-12340042

African Charter on Human Rights and the European Convention on Human Rights. Available at https://treaties.un.org/doc/Publication/UNTS/Volume\%201520/volume-1520-I-26363English.pdf [accessed 16 April 2021]

American Anthropological Association. Statement on Human Rights. American Anthropologist, vol. 49, n. 4, part 1, p.539-543, Oct-Dec 1947. p. 539

American Convention on Human Rights (Adopted at the Inter-American Specialized Conference on Human Rights, San José, Costa Rica, 22 November 1969). Available at https://www.cidh.oas.org/basicos Lenglish/basic3.american \%20convention.htm [accessed 16 April 2021]

Barreto, José-Manuel. (2018). "Decolonial Thinking and the Quest for Decolonising Human Rights". Asian journal of social science 46, 484-502. DOI: 10.1163/15685314-04604006

Chakrabarty, Dipesh. (2007). "Provincializing Europe: Postcolonial Thought and Historical Difference". Princeton: PUP.

Chalabi, Azadeh. (10 December 2020). A Rapprochement between the Universality of Human Rights and Cultural Relativism https://www.liverpool.ac.uk/law-and-social-justice/blog/a-rapprochementbetween-the-universality-of-human-rights-and-cultural-relativism/

Chepel, Olga. (2019). "Characteristics of property rights protection in European Court of Human Rights decisions". European Journal of Law and Public Administration. Volume 6 (2), 1-10 https://doi.org/10.18662/elipa/80

Chestnov, I. L. (1999). "Are human rights universal? (Controversial reflections on the Universal Declaration of Human Rights)". Jurisprudence, 1 [in Russian]

Convention on the Elimination of All Forms of Discrimination against Women Available at https://www.ohchr.org/en/professionalinterest/pages/cedaw.aspx [accessed 24 April 2021]

Convention on the Rights of the Child, and the 1981 Declaration on the Elimination of All Forms of Intolerance and of Discrimination Based on Religion or Belief Available at https://www.ohchr.org/en/professionalinterest/pages/religionorbelief.aspx_[accessed 24 April 2021]

Donnelly, Jack. (2003). "Universal Human Rights in Theory and Practice”. 2. ed. Ithaca and London: Cornell University Press.

European Convention on Human Rights. Convention for the Protection of Human Rights and Fundamental Freedoms, as amended by Protocols No. 11 and 14. Rome, 4.XI.1950 / Council of Europe. European Treaty Series. 1950. No. 5. Available at https://www.echr.coe.int/documents /convention eng.pdf [accessed 16 April 2021]

Gunn, T. Jeremy. (2020). “Do Human Rights Have a Secular, Individualistic \& Anti-Islamic Bias?” Dadalus, the Journal of the American Academy of Arts \& Sciences 149 (3): 148-169. https://direct.mit.edu/daed/article/149/3/148/94865/Do-Human-Rights-Have-a-SecularIndividualistic-amp DOI: https://doi.org/10.1162/daed_a 01809

Gunn T. Jeremy and Lagresa Alvaro, (2016.) "The Organisation of Islamic Cooperation: Universal Human Rights, Islamic Values, or Raisons d'État?” Human Rights and International Legal Discourse 10 (2) (2016): 248-274. https://doi.org/10.1162/daed a 01809 available at: https://direct.mit.edu/daed/article $\angle 149 / 3 / 148 / 94865 /$ Do-Human-Rights-Have-a-Secular-Individualistic-amp

Higgins, Tracy E. (1996). "Anti-Essentialism, Relativism, and Human Rights". Harvard Women's Law Journal, vol. 19, 89-126, 1996.

Huntington, Samuel P. (1996). "The Clash of Civilizations and the Remaking of World Order".

International Covenant on Civil and Political Rights. Available at https://www.ohchr.org/en Lprofessionalinterest/pages/ccpr.aspx [accessed 24 April 2021] 
Karvatska Svitlana, Blikhar Mariia \& Huralenko Nataliia (2021). "Evolutionary trends in the interpretation of the European Court of Human Rights under the European Convention on Human Rights". Cuestiones Politicas, Vol. 39, $\mathrm{N}^{\circ} 68$ (Enero - Junio), 88-102 DOI: https://doi.org/10.46398/cuestpol.3968.04

Karvatska, S., Zamorska, L. (2018). "Human Rights Principles Interpretation in the Context of the ECHR". European Journal of Law and Public Administration. Vol. 5. No. 2. P. 1-14. available at: http://lumenpublishing.com/journals/index.php/ejlpa/article/view/860

Kroetz, Flávia Saldanha. (2016). "Between global consensus and local deviation: a critical approach on the universality of human rights, regional human rights systems and cultural diversity". Revista de Investigacões Constitucionais, vol.3 no.1 Curitiba Jan./Apr. Epub Apr 15 DOI: https://doi.org/10.5380/rinc.v3i1.45109

Krysachenko, V. S. (ed.) (2004). "Ukrainian political nation: genesis, state, prospects". Kyiv: NISD. [in Ukrainian]

Lukasheva, E. A. (2007). "Human rights in the context of the conflict of cultures". Bulletin of the Russian Academy of Sciences. 77, (2), [in Russian]

Multilateral African Charter on Human and Peoples' Rights. Concluded at Nairobi on 27 June 1981. Available at https://treaties.un.org/doc/Publication/UNTS/Volume\%201520/volume-1520-I-26363-English.pdf [accessed 16 April 2021]

Mytsyk, V. V. (2010). "Human rights in international law. International legal protection mechanisms”. Kiev. nat. Taras Shevchenko University. Kiev: Rays [in Ukrainian]

Mutua, Makau Wa. (1996). "The Ideology of Human Rights". Virginia Journal of International Law, vol. 36, 589658.

Nussbaum, Martha. (February 1999). In Defense of Universal Values. https://humanities-web.s3.us-east2.amazonaws.com/philosophy/prod/2018-10/In $\% 20$ Defense $\% 20$ of $\% 20$ Universal $\% 20$ Values.pdf

Rymarenko, Y. I., Shklyar, L. E. \& Rymarenko, S. Y. (2001). „Ethnostate studies. Theoretical and methodological principles". Kyiv: Institute of State and Law. V.M. Koretsky NAS of Ukraine. [in Ukrainian]

Third Committee of the United Nations General Assembly, A/C.3/SR.125 (November 9, 1948).

UN Educational, Scientific and Cultural Organisation. (2 November 2001). UNESCO Universal Declaration on Cultural Diversity, 3, article 4. Available at: https://www.refworld.org/docid/435cbcd64.html [accessed 16 April 2021]

Universal Declaration of Human Rights, 1948. G.A. Res. 217A (III), Official Records of the Third Session of the General Assembly, Part I, U.N. Doc. A/810 (1948), 71.

Yuriychuk Olena. (2018). Legal multiculturalism: axiological dimension. Thesis of Candidate of Sciences. [in Ukrainian]

Verkhovna Rada of Ukraine. (1996). Constitution of Ukraine: Law of Ukraine of June 28 , 1996 № 254k / 96VR / Information of the Verkhovna Rada of Ukraine, 30, 141. Available at https://zakon.rada.gov.ua laws/show $/ 254 \% \mathrm{D} 0 \% \mathrm{BA} / 96-\% \mathrm{D} 0 \% \mathrm{~B} 2 \% \mathrm{D} 1 \% 80 \#$ Text [accessed 16 April 2021]. [in Ukrainian] 